\title{
中庸熱フライアッシュセメントを用いたコンクリー トの耐凍害性に及ぼす凝結過程の空気量変化の影響
}

\author{
坂田 昇* $*^{1}$ 菅俣 匠 $*^{2} \cdot$ 林 $大 介 *^{3} \cdot$ 橋本 学*4
}

\begin{abstract}
概要 : フライアッシュを用いたコンクリートの中でも, ダムコンクリートで一般に用いられる中庸熱フライアッシュ セメントに着目し, コンクリートの凝結過程における空気量の変化が, 気泡組織と耐凍害性に及ぼす影響を明らかに することを目的に検討を行った。中庸熱フライアッシュセメントを用いたコンクリートは, 普通ポルトランドセメン 卜を用いた場合に比べてフレッシュ時よりも硬化後の空気量が大幅に低下寸る傾向にあり，これにより耐凍害性が劣 ると考えられた。フレッシュ時の空気量を従来よりも大きく設定することにより，硬化後の空気量の低下を抑制し， 耐凍害性を確保することが可能となった。硬化後の空気量が低下寸る理由としては, 普通ポルトランドセメントを用 いる場合に比べて中庸熱フライアッシュセメントを用いたコンクリート中の気泡がブリーディング水の流れによっ て破泡，合泡する可能性が示唆され，ブリーディングが多い場合にその傾向が顕著になることを実験的に確認した。 キーワード : フライアッシュ,ブリーディング, 気泡組織, 気泡間隔係数, 耐凍害性
\end{abstract}

\section{1. はじめに}

近年，寒冷地におけるコンクリートダムにおいて，表 面部の骨材がポップアウトを起こすなど, 凍結融解作用 によるものと考えられる劣化現象が多数見受けられる 1),2),3)。通常, ダムコンクリートは, 近傍で良質な原石山 を確保し，良品質な骨材のみをコンクリート用骨材とし て用いており, また, 表面部のコンクリートは, 外部コ ンクリートと呼ばれる水セメント比が $50 \%$ 以下の耐久性 を十分に満足する配合である。

ダムコンクリートでは，一般的に温度上昇を抑制する 目的で，フライアッシュをセメントの質量比で 20〜30\% 置換しているが, フライアッシュを用いたコンクリート は，普通コンクリートに比べて耐凍害性に劣るという報 告 ${ }^{4)}$ がされている。また，コンクリート標準示方書 [ダ ムコンクリート編］においては, 骨材の耐凍害性を評価 する際の試験方法として, JIS A 1148 「ンクリートの凍 結融解試験方法 (A 法)」に準拠した, 普通ポルトランド セメントを用いた仕様が示されており,このことからも， フライアッシュを用いたコンクリートが而凍害性に劣る 可能性があることを示唆している。

フライアッシュを用いたコンクリートの耐凍害性が普 通コンクリートよりも劣るメカニズムとして, フライア
ッシュに含まれる未燃炭素が $\mathrm{AE}$ 剂を吸着するために, $\mathrm{AE}$ 剂の効果が得られにくく, さらに, 連行した空気が 経時に伴って減少しや寸い5)ことが考えられる。

また，コンクリートの耐凍害性については，ブリーデ イングと高い相関があり，ブリーディングが多いコンク リートほど，耐凍害性が低下寸る傾向にあることが報告 されている ${ }^{6)}$ 。ブリーディングが多いコンクリートの耐 凍害性が低下寸る機構として, 阿波らは, ブリーディン グ中において上昇した気泡の集合，合体などの現象が生 じることを推察している ${ }^{7)}$ 。フライアッシュを用いたコ ンクリートの場合, 凝結が遅れるためブリーディングが 増加する傾向にあり ${ }^{8)}$ ，このことも，耐凍害性に影響を 及ぼしている可能性がある。

いずれの理由においても，コンクリートの凝結過程に おいて，凍結融解に伴う水圧を緩和する役割を果たす気 泡の量が減少するために，耐凍害性が低下寸るという機 構が推察される。しかし，これまでに，コンクリートの 凝結過程における気泡組織の変化に着眼した研究は, ほ とんどされておらず，耐凍害性に及ぼす影響についても 明らかにされていない。また，今後のダム建設において は，公共事業費の削減や自然保護・保全に対する意識の 高まりから，従来では廃棄していた低品質な骨材や，掘 削ズリなどの現地発生材を使用するといった材料の合理

\footnotetext{
*1 鹿島建設 (株) 技術研究所 土木材料グループ グループ長 博士（工学） *2 BASF ポゾリス (株) 混和剤開発グループグループリーダー＼cjkstart博士（工学） （正会員） $\bar{\top} 182-0036$ 東京都調布市飛田給 2-19-1 （正会員） 广253-0071 神奈川県茅ヶ崎市萩園 2722 *3 鹿島建設 (株) 技術研究所 土木材料グループ 主任研究員 博士（工学）（正会員） ̄182-0036 東京都調布市飛田給 2-19-1 *4 鹿島建設 (株) 技術研究所 土木材料グループ 研究員 （正会員） ₹182-0036 東京都調布市飛田給 2-19-1
} 
化や有効利用を積極的に図ることが必要となっており, さらなる耐凍害性の低下が懸念される。

そこで，本研究では，フライアッシュを用いたコンク リートの中でも, ダムコンクリートで一般に用いられて いる中庸熱フライアッシュセメントに着目し，コンクリ 一トの凝結過程における空気量の变化を把握し, 気泡組 織と耐凍害性との関係を明らかにすることを目的として， 実験的に検討した。

\section{2. フレッシュおよび硬化コンクリートの空気 量が凍結融解抵抗性に及ぼす影響}

フレッシュコンクリートおよび硬化コンクリートの空 気量が凍結融解抵抗性に及ぼす影響を検討するため，フ ライアッシュ $30 \%$ 混入中庸熱ポルトランドセメント（以 下，MF30）を用いたコンクリートについて，コンクリー 卜の凝結過程における空気量の変化を把握する以下の実 験を行った。

\section{1 使用材料および配合}

使用材料を表一 1 に示す。本実験では, セメントに MF30 を用いた。表一2 に使用したセメントの物理化学 試験結果を示す。細・粗骨材には河床砂磁を用い, 粗骨 材の最大骨材寸法は $150 \mathrm{~mm}$ とした。実験に用いた化学 混和剂は, リグニンスルホン酸化合物を主成分とする $\mathrm{AE}$ 減水剂および変性ロジン酸化合物系陰イオン界面活 性剂を主成分とする $\mathrm{AE}$ 助剂である。なお，練混ぜ水に は JIS A 5308 の規格を満足する河川水を用いた。

骨材の物性值を表一3に示す。使用した細・粗骨材は 全ての物性值が JIS A 5308 の規格值を満足したものであ る。特に，硫酸ナトリウムによる安定試験結果について は, 細骨材は規格值の $10.0 \%$ に対して $1.40 \%$ で, 粗骨材 については, 規格值の $12.0 \%$ に対し, 粗骨材径が $40 \mathrm{~mm}$ から $150 \mathrm{~mm}$ のもので $0.00 \%, 20 \mathrm{~mm}$ から $40 \mathrm{~mm}$ のもので 1.10\%であることから十分に耐凍害性を有する骨材であ ると判断できる。

表－4 に粗骨材の最大寸法 $150 \mathrm{~mm}$ のコンクリートの 配合を示す。配合 No.1, No.2, No.3 およびNo.4 は, そ れぞれ目標空気量を $3.0 \% ， 3.5 \% ， 4.0 \%$ おび $5.0 \%$ とし た。空気量の増減は, 表一1 に示す $\mathrm{AE}$ 助剤の添加量に よって調整した。その他の配合条件はすべて同じとした。 なお，表－4 に示す目標スランプ $3.0 \mathrm{~cm}$ は $40 \mathrm{~mm}$ ふるるい でウェットスクリーニングしたコンクリートについて のものである。表－5および表－6に，40mm ふるいおよ び20mm ふるいでウェットスクリーニングしたコンクリ 一トの配合をそれぞれ示す。

\section{2 試験方法}

フレッシュコンクリートのスランプ試験は, JIS A 1101 に従い, 練上り後のコンクリートを $40 \mathrm{~mm}$ ふるいにてウ エットスクリーニングを行ったものを試料とした。また，
表-1 使用材料

\begin{tabular}{|c|c|c|}
\hline 種 類 & 記 号 & 摘 要 \\
\hline $\begin{array}{c}\text { フライ仍ッシュ 30\%混入 } \\
\text { 中庸熱ポルトランドセメト }\end{array}$ & MF30 & $\begin{array}{l}\text { 密度: } 2.89 \mathrm{~g} / \mathrm{cm}^{3} \\
\text { 比表面積 : } 3,730 \mathrm{~cm}^{2} / \mathrm{g}\end{array}$ \\
\hline 細骨材 & $\mathrm{S}$ & $\begin{array}{l}\text { 密度: } 2.58 \mathrm{~g} / \mathrm{cm}^{3} \text { (表乾) } \\
\text { 吸水率 }: 1.89 \%\end{array}$ \\
\hline $\begin{array}{c}\text { 粗骨材 } 1 \\
(150 \sim 80 \mathrm{~mm})\end{array}$ & G1 & $\begin{array}{l}\text { 密度: } 2.65 \mathrm{~g} / \mathrm{cm}^{3} \text { (表乾) } \\
\text { 吸水率 }: 0.76 \%\end{array}$ \\
\hline $\begin{array}{c}\text { 粗骨材 } 2 \\
(80 \sim 40 \mathrm{~mm})\end{array}$ & G2 & $\begin{array}{l}\text { 密度: } 2.66 \mathrm{~g} / \mathrm{cm}^{3} \text { (表乾) } \\
\text { 吸水率 }: 0.83 \%\end{array}$ \\
\hline $\begin{array}{c}\text { 粗骨材 } 3 \\
(40 \sim 20 \mathrm{~mm})\end{array}$ & G3 & $\begin{array}{l}\text { 密度: } 2.66 \mathrm{~g} / \mathrm{cm}^{3} \text { (表乾) } \\
\text { 吸水率: } 0.82 \%\end{array}$ \\
\hline $\begin{array}{c}\text { 粗骨材 } 4 \\
(20 \sim 5 \mathrm{~mm})\end{array}$ & G4 & $\begin{array}{l}\text { 密度: } 2.64 \mathrm{~g} / \mathrm{cm}^{3} \text { (表乾) } \\
\text { 吸水率: } 1.20 \%\end{array}$ \\
\hline $\mathrm{AE}$ 減水剤 & Ad1 & リグニンスルボ酸化合物 \\
\hline $\mathrm{AE}$ 助剂 & $\mathrm{Ad} 2$ & $\begin{array}{l}\text { 変性口ジン酸化合物系 } \\
\text { 陰仏界面活性剂 }\end{array}$ \\
\hline 水 & $\mathrm{W}$ & 河川水 \\
\hline
\end{tabular}

表ー2 使用したセメント(MF30)の物理化学試験結果

\begin{tabular}{|c|c|c|c|c|}
\hline \multicolumn{3}{|c|}{ 項 目 } & 規格值 ${ }^{* 1)}$ & 試験成績 \\
\hline \multicolumn{2}{|l|}{ 密度 } & $\mathrm{g} / \mathrm{cm}^{3}$ & - & 2.89 \\
\hline \multicolumn{2}{|l|}{ 比表面積 } & $\mathrm{cm}^{2} / \mathrm{g}$ & 2,500 以上 & 3,730 \\
\hline \multirow{3}{*}{ 凝結 } & 水量 & $\%$ & - & 29.4 \\
\hline & 始発 & h-min & 1-00 以上 & $3-35$ \\
\hline & 終結 & h-min & 10-00 以下 & $4-35$ \\
\hline \multicolumn{3}{|c|}{ 安定度(パット法) } & - & 良 \\
\hline \multirow{3}{*}{ 圧縮強さ } & $3 \mathrm{~d}$ & $\mathrm{~N} / \mathrm{mm}^{2}$ & 7.0 以上 & 12.5 \\
\hline & $7 \mathrm{~d}$ & $\mathrm{~N} / \mathrm{mm}^{2}$ & 13.5 以上 & 18.0 \\
\hline & $28 \mathrm{~d}$ & $\mathrm{~N} / \mathrm{mm}^{2}$ & 29.5 以上 & 39.7 \\
\hline \multicolumn{2}{|c|}{ 酸化マグネシウム } & $\%$ & 5.0 以下 & 0.63 \\
\hline \multicolumn{2}{|c|}{ 三酸化硫黄 } & $\%$ & 3.0 以下 & 1.42 \\
\hline \multicolumn{2}{|c|}{ フライ仍ッュュの強熱減量 } & $\%$ & 5.0 以下 & 1.8 \\
\hline
\end{tabular}

*1) JIS R 5210 のフライアッシュセメント C 種に準拠

フレッシュコンクリートの空気量は, JIS A 1128 に従い, 練上り後のコンクリートを $40 \mathrm{~mm}$ および $20 \mathrm{~mm}$ ふるいに て，ウェットスクリーニングを行ったものをそれぞれ試 験に供した。

凍結融解試験は，JIS A 1148-A 法（水中凍結水中融解 法）に従い, 凍結融解サイクル 300 サイクルまで実施し た。供試体は $100 \times 100 \times 400 \mathrm{~mm}$ の角柱を用い， $20 \mathrm{~mm}$ ふ るいでウェットスクリーニングをしたコンクリートを 用いて作製した。コンクリートの凍結融解抵抗性は，た わみ振動の一次共鳴振動数より算出した相対動弾性係 数および供試体の質量により評価した。また, 供試体の 本数は 3 本とし, 3 本の平均值の相対動弾性係数および 質量を算出した。試験開始材齢は 28 日とし, その間, $20^{\circ} \mathrm{C}$ 一定のもと, 水中養生を行った。なお, 試験開始材 齢の影響を把握する試験では，開始材齢 91 日において も試験を行った。

気泡間隔係数の測定は, $20 \mathrm{~mm}$ ふるいでウェットスク リーニングしたコンクリートを対象とし， $\phi 150 \times 300 \mathrm{~mm}$ の円柱供試体の中心部を厚さ $20 \mathrm{~mm}$ で切断した試験片を 
用いて行った。なお，供試体の本数は 1 本，測定回数は 1 回とした。測定方法は, ASTM C 457（リニアトラバー ス法）に従い，硬化コンクリートの空気量および気泡間 隔係数を算出した。

圧縮強度試験は JIS A 1108 に従い，材齢 7 日，28 日お よび 91 日で実施した。試験は, $40 \mathrm{~mm}$ ふるいでウェット スクリーニングしたコンクリートで作製した $\phi 150 \times$ $300 \mathrm{~mm}$ の円柱供試体を用いて行った。なお，供試体はい
ずれも, 試験開始材齢まで $20^{\circ} \mathrm{C}$ 一定のもと, 水中養生を 行った。

\section{3 試験結果および考察}

表ー7 に，各配合の $20 \mathrm{~mm}$ ふるいでウェットスクリー ニングしたコンクリートのフレッシュ時の空気量, 硬化 後の空気量および気泡間隔係数をそれぞれ示す。また, 図ー1 にフレッシュ時の空気量と硬化後の空気量の減少 量の関係を示す。図表より，フレッシュ時の空気量が

\section{表 -3 骨材の物性値}

\begin{tabular}{|c|c|c|c|c|c|c|c|c|}
\hline \multirow[b]{2}{*}{ 項 目 } & \multirow[b]{2}{*}{ 単位 } & \multirow{2}{*}{$\begin{array}{c}\text { 細骨材 } \\
\mathrm{S}\end{array}$} & \multirow{2}{*}{$\begin{array}{l}\text { 規格值 } \\
\text { (JIS A 5308) }\end{array}$} & \multicolumn{4}{|c|}{ 粗骨材 } & \multirow{2}{*}{$\begin{array}{c}\text { 規格值 } \\
\text { (JIS A 5308) }\end{array}$} \\
\hline & & & & $\begin{array}{c}150-80 \\
\mathrm{G} 1\end{array}$ & $\begin{array}{c}80-40 \\
\text { G2 }\end{array}$ & $\begin{array}{c}40-20 \\
\text { G3 }\end{array}$ & $\begin{array}{c}20-05 \\
\text { G4 }\end{array}$ & \\
\hline 表乾密度 & $\mathrm{kg} / \mathrm{m}^{3}$ & 2.58 & 2.50 以上 & 2.65 & 2.66 & 2.66 & 2.64 & 2.50 以上 \\
\hline 吸水率 & $\%$ & 1.79 & 3.50 以下 & 0.64 & 0.66 & 0.87 & 1.02 & 3.00 以下 \\
\hline 単位容積質量 & $\mathrm{kg} / \mathrm{m}^{3}$ & - & - & 1.60 & 1.64 & 1.65 & 1.64 & - \\
\hline 粗粒率 & - & - & - & \multicolumn{4}{|c|}{8.69} & - \\
\hline 実積率 & $\%$ & 66.2 & - & 60.5 & 61.9 & 62.9 & 62.8 & - \\
\hline 粘土塊量 & $\%$ & 0.50 & 1.00 以下 & 0.20 & 0.20 & 0.20 & 0.20 & 0.25 以下 \\
\hline すりへり減量 & $\%$ & - & - & - & 20.2 & \multicolumn{2}{|c|}{23.6} & 40.0 以下 \\
\hline 微粒分量 & $\%$ & 2.54 & 9.00 以下 & 0.20 & 0.18 & 0.19 & 0.15 & 1.00 以下 \\
\hline 安定性試験 & $\%$ & 1.40 & 10.0 以下 & \multicolumn{2}{|c|}{0.00} & \multicolumn{2}{|c|}{1.10} & 12.0 以下 \\
\hline アル别归反応性 & - & $\begin{array}{l}\text { 無害 } \\
\end{array}$ & - & \multicolumn{4}{|c|}{ 無害 } & - \\
\hline 有機不純物 & - & 淡い & - & \multicolumn{4}{|c|}{-} & - \\
\hline $\begin{array}{c}\text { 密度 } 1.95 \text { の液体に浮 } \\
<も の \\
\end{array}$ & $\%$ & 0.30 & 0.5 以下 & \multicolumn{5}{|c|}{0.00} \\
\hline
\end{tabular}

表－4 コンクリートの配合（粗骨材の最大寸法 150mm）

\begin{tabular}{|c|c|c|c|c|c|c|c|c|c|c|c|c|c|c|c|}
\hline \multicolumn{7}{|c|}{ 配合条件 } & \multicolumn{9}{|c|}{ 単位量(kg/m³) } \\
\hline \multirow[b]{2}{*}{$\begin{array}{l}\text { 配合 } \\
\text { No. }\end{array}$} & \multirow[b]{2}{*}{$\begin{array}{l}\text { セメント } \\
\text { 種類 }\end{array}$} & \multirow{2}{*}{$\begin{array}{c}\text { 粗骨 } \\
\text { 材の } \\
\text { 最大 } \\
\text { 寸法 } \\
(\mathrm{mm})\end{array}$} & \multirow[b]{2}{*}{$\begin{array}{l}\mathrm{W} / \mathrm{C} \\
(\%)\end{array}$} & \multirow[b]{2}{*}{$\begin{array}{l}\mathrm{s} / \mathrm{a} \\
(\%)\end{array}$} & \multirow[b]{2}{*}{$\begin{array}{c}\text { 目標 } \\
\text { 空気 } \\
\text { 量 } \\
(\%)\end{array}$} & \multirow{2}{*}{$\begin{array}{c}\text { 目標 }{ }^{* 1)} \\
\text { 久ラ } \\
\text { ンプ } \\
(\mathrm{cm})\end{array}$} & \multirow[b]{2}{*}{$\begin{array}{l}\text { 水 } \\
W\end{array}$} & \multirow[b]{2}{*}{$\begin{array}{l}\text { セx } \\
\text { ソト } \\
\mathrm{C}\end{array}$} & \multirow{2}{*}{$\begin{array}{c}\text { 細 } \\
\text { 骨 } \\
\text { 材 } \\
\mathrm{S}\end{array}$} & \multicolumn{4}{|c|}{ 粗骨材 G } & \multirow[b]{2}{*}{$\begin{array}{l}\text { Ad1 } \\
(\mathrm{C} \times \%)\end{array}$} & \multirow[b]{2}{*}{$\begin{array}{c}\left.\mathrm{Ad} 2^{* 2}\right) \\
\text { (A) }\end{array}$} \\
\hline & & & & & & & & & & $\begin{array}{c}150 \sim 80 \\
\mathrm{G} 1\end{array}$ & $\begin{array}{c}80 \sim 40 \\
\text { G2 }\end{array}$ & $\begin{array}{c}40 \sim 20 \\
\text { G3 }\end{array}$ & $\begin{array}{c}20 \sim 05 \\
\text { G4 }\end{array}$ & & \\
\hline No.1 & \multirow{4}{*}{ MF30 } & \multirow{4}{*}{150} & \multirow{4}{*}{45.2} & \multirow{4}{*}{23.0} & 3.0 & \multirow{4}{*}{3.0} & 95 & 210 & 475 & 410 & 410 & 411 & 408 & 1.0 & 33 \\
\hline No. 2 & & & & & 3.5 & & 95 & 210 & 472 & 407 & 407 & 409 & 405 & 1.0 & 55 \\
\hline No.3 & & & & & 4.0 & & 95 & 210 & 470 & 404 & 404 & 406 & 403 & 1.0 & 70 \\
\hline No.4 & & & & & 5.0 & & 95 & 210 & 465 & 399 & 399 & 401 & 398 & 1.0 & 100 \\
\hline
\end{tabular}

*1)40mm ふるいでウェットスクリーニングしたコンクリートの目標スランプ

*2)Ad2 はセメント質量に対して $0.001 \%$ 基本量 $1 \mathrm{~A}$ とした。

表－5 粗骨材の最大寸法 40mm 換算時のコンクリートの配合

\begin{tabular}{|c|c|c|c|c|c|c|c|c|c|c|c|c|c|}
\hline \multicolumn{7}{|c|}{ 配合条件 } & \multicolumn{7}{|c|}{ 単位量 $\left(\mathrm{kg} / \mathrm{m}^{3}\right)$} \\
\hline \multirow{2}{*}{$\begin{array}{c}\text { 配合 } \\
\text { No. }\end{array}$} & \multirow{2}{*}{$\begin{array}{l}\text { セメト } \\
\text { 種類 }\end{array}$} & \multirow{2}{*}{$\begin{array}{c}\text { 粗骨材の } \\
\text { 最大寸法 } \\
(\mathrm{mm})\end{array}$} & \multirow{2}{*}{$\begin{array}{l}\mathrm{W} / \mathrm{C} \\
(\%)\end{array}$} & \multirow{2}{*}{$\begin{array}{l}\mathrm{s} / \mathrm{a} \\
(\%)\end{array}$} & \multirow{2}{*}{$\begin{array}{l}\text { 換算 } \\
\text { 空気 } \\
\text { 量(\%) }\end{array}$} & \multirow{2}{*}{$\begin{array}{r}\text { 目標 } \\
\text { スランソプ } \\
(\mathrm{cm})\end{array}$} & \multirow{2}{*}{$\begin{array}{l}\text { 水 } \\
\text { W }\end{array}$} & \multirow{2}{*}{$\begin{array}{c}\text { セメント } \\
\mathrm{C}\end{array}$} & \multirow{2}{*}{$\begin{array}{c}\text { 細骨 } \\
\text { 材 } \\
\text { S }\end{array}$} & \multicolumn{2}{|c|}{ 粗骨材 G } & \multirow{2}{*}{$\underset{(\mathrm{C} \times \%)}{\operatorname{Ad} 1}$} & \multirow{2}{*}{$\begin{array}{c}\mathrm{Ad}^{*}{ }^{* 1)} \\
\text { (A) }\end{array}$} \\
\hline & & & & & & & & & & $\begin{array}{c}40 \sim 20 \\
\text { G3 }\end{array}$ & $\begin{array}{c}20 \sim 05 \\
\text { G4 }\end{array}$ & & \\
\hline No.1 & \multirow{4}{*}{ MF30 } & \multirow{4}{*}{40} & \multirow{4}{*}{45.2} & \multirow{4}{*}{-} & 4.3 & \multirow{4}{*}{3.0} & 137.5 & 303.8 & 687 & 595 & 590 & 1.0 & 33 \\
\hline No.2 & & & & & 5.0 & & 137.0 & 302.9 & 681 & 590 & 584 & 1.0 & 55 \\
\hline No.3 & & & & & 5.7 & & 136.6 & 301.9 & 676 & 584 & 579 & 1.0 & 70 \\
\hline No.4 & & & & & 7.1 & & 135.8 & 300.2 & 665 & 573 & 569 & 1.0 & 100 \\
\hline
\end{tabular}

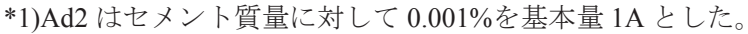

表一6 粗骨材の最大寸法 $20 \mathrm{~mm}$ 換算時のコンクリートの配合

\begin{tabular}{|c|c|c|c|c|c|c|c|c|c|c|c|c|}
\hline \multicolumn{7}{|c|}{ 配合条件 } & \multicolumn{6}{|c|}{ 単位量 $\left(\mathrm{kg} / \mathrm{m}^{3}\right)$} \\
\hline $\begin{array}{l}\text { 配合 } \\
\text { No. }\end{array}$ & $\begin{array}{l}\text { セメン } \\
\text { 種類 }\end{array}$ & $\begin{array}{c}\text { 粗骨材の } \\
\text { 最大寸法 } \\
(\mathrm{mm})\end{array}$ & $\begin{array}{l}\mathrm{W} / \mathrm{C} \\
(\%)\end{array}$ & $\begin{array}{l}\text { s/a } \\
(\%)\end{array}$ & $\begin{array}{l}\text { 換算 } \\
\text { 空気量 } \\
(\%)\end{array}$ & $\begin{array}{r}\text { 目標 } \\
\text { スラフプ } \\
(\mathrm{cm})\end{array}$ & $\begin{array}{l}\text { 水 } \\
\mathrm{W}\end{array}$ & $\begin{array}{c}\text { セメント } \\
\mathrm{C}\end{array}$ & $\begin{array}{c}\text { 細骨材 } \\
\text { S }\end{array}$ & $\begin{array}{c}\text { 粗骨材 } \\
20 \sim 05 \\
\text { G4 }\end{array}$ & $\begin{array}{c}\text { Ad1 } 1 \\
(\mathrm{C} \times \%)\end{array}$ & $\begin{array}{c}\mathrm{Ad}^{* 11} \\
\text { (A) }\end{array}$ \\
\hline No.1 & \multirow{4}{*}{ MF30 } & \multirow{4}{*}{20} & \multirow{4}{*}{45.2} & \multirow{4}{*}{-} & 5.6 & \multirow{4}{*}{-} & 177.0 & 391.3 & 885 & 760 & 1.0 & 33 \\
\hline No. 2 & & & & & 6.5 & & 176.0 & 389.1 & 875 & 750 & 1.0 & 55 \\
\hline No.3 & & & & & 7.4 & & 174.9 & 386.7 & 866 & 742 & 1.0 & 70 \\
\hline No.4 & & & & & 9.1 & & 173.1 & 382.7 & 847 & 725 & 1.0 & 100 \\
\hline
\end{tabular}

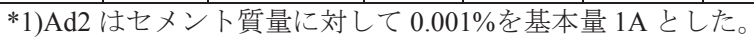


6.6\%以下の場合, 硬化後の空気量の減少量が $2.5 \%$ と非 常に大きいことが分かる。これに対して, フレッシュ時 の空気量が 7.4\%以上の場合には, 硬化後の空気量の減少 量が $0.5 \%$ 程度と比較的小さい。奥野らは, フライアッシ ユ中に含まれる未燃炭素量が多く含まれる場合, $\mathrm{AE}$ 剂 の使用量が増加し, フレッシュコンクリートの経時変化 による空気量の減少も大きくなる傾向にあることを示 している ${ }^{9)}$ 。た, 千歩らは, 60 分静置を行ったフライ アッシュを用いたコンクリートは普通コンクリートに 比べ, 空気量の低下が大きく, 気泡間隔係数についても 変化が大きいと報告している ${ }^{5)}$ 。今回の実験で, 硬化後 の空気量が大きく減少したことについては, これらの既 往の研究と同様に, フライアッシュを用いたコンクリー トによる特性であると考えられる。一方，フライアッシ ユを用いたコンクリートであっても, 中庸熱フライアッ シュセメントを用いた場合, ある一定量以上, フレッシ ユ時に空気量を確保すれば, 硬化後の空気量の減少は少 なくなることが今回の実験で明らかとなった。その理由 については定かではないが, フレッシュ時の空気量を多 く寸ることで, ブリーディングが抑制され，そのことが 一要因であると考えられる。

図ー2 にフレッシュ時および硬化後の空気量と気泡間 隔係数の関係を示寸。図に示すように, フレッシュ時, 硬化後ともに空気量と気泡間隔係数に相関があり, 特に 硬化後の空気量と高い相関（相関係数：0.996）があるこ とが分かる。

各配合の凍結融解試験結果として, 図一 3 に凍結融解 サイクル数と相対動弾性係数の関係を, 図一 4 に凍結融 解サイクル数と質量減少率の関係を, それぞれ示寸。図 に示寸ように, 硬化後の空気量が大幅に減少した配合 No.1 および配合 No.2 は，ともに 300 サイクルで相対動 弾性係数が $60 \%$ を下回った。これに対して, フレッシュ 時の空気量を $7.4 \%$ 以上として硬化後の空気量の減少量 が少なかった配合 No.3 および配合 No.4 は，300 サイク ルまで相対動弾性係数がほぼ $100 \%$ を維持し, 高い凍結 融解抵抗性を示した。このように, 中庸熱フライアッシ ユセメントを用いたコンクリートの場合でも, 空気量を 多くして硬化後の空気量を所定量以上確保することによ って, 凍結融解抵抗性が得られるものと考えられる。

図-5 に各配合の気泡分布を示す。図に示すように, 凍結融解抵抗性に優孔る配合 No.3 および配合 No.4 は, 気泡径 0.10 以上 $0.15 \mathrm{~mm}$ 末満（以下, 代表值である気泡 径 $0.125 \mathrm{~mm}$ と標記）の空気量が多くなっている。図ー6 に気泡径 $0.125 \mathrm{~mm}$ の空気量とコンクリートの空気量の 関係を, 図一7 に気泡径 $0.125 \mathrm{~mm}$ の空気量と気泡間隔係 数の関係をそれぞれ示す。眓に示すように, 気泡径 $0.125 \mathrm{~mm}$ の空気量は, コンクリートの空気量, 気泡間隔 係数と高い相関にあり, 凍結融解抵抗性に大きく影響す るものと考えられる。
表-7 空気量および気泡間隔係数

\begin{tabular}{|c|c|c|c|c|c|}
\hline $\begin{array}{l}\text { 配合 } \\
\text { No. }\end{array}$ & $\begin{array}{l}\text { 粗骨 } \\
\text { 材の } \\
\text { 最大 } \\
\text { 寸法 } \\
(\mathrm{mm})\end{array}$ & $\begin{array}{c}\text { (1)フレッシュ } \\
\text { 時空気量 } \\
\text { (\%) }\end{array}$ & $\begin{array}{c}\text { (2)硬化後 } \\
\text { 空気量 } \\
\text { (\%) }\end{array}$ & $\begin{array}{c}\text { (1)-(2) } \\
(\%)\end{array}$ & $\begin{array}{c}\text { 気泡間 } \\
\text { 隔係数 } \\
(\mu \mathrm{m})\end{array}$ \\
\hline No.1 & \multirow{4}{*}{20} & 4.9 & 2.4 & -2.5 & 303 \\
\hline No.2 & & 6.6 & 4.1 & -2.5 & 265 \\
\hline No. 3 & & 7.4 & 6.9 & -0.5 & 211 \\
\hline No.4 & & 9.8 & 9.2 & -0.6 & 144 \\
\hline
\end{tabular}

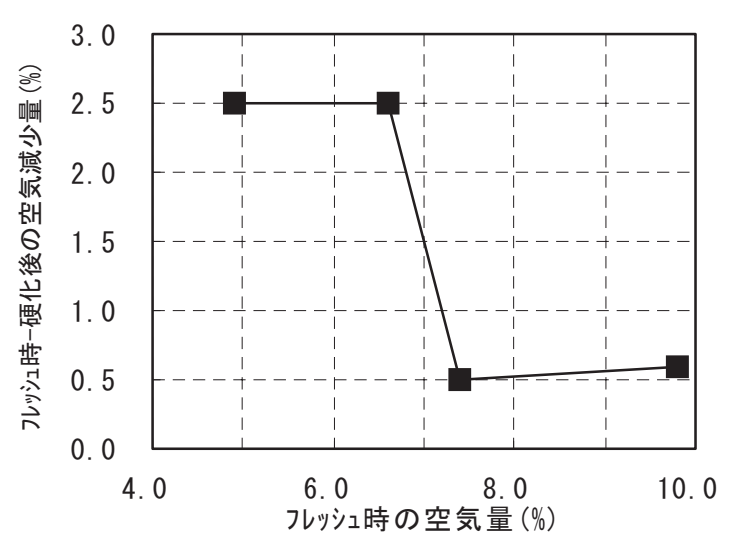

図-1 フレッシュ時の空気量と 硬化後の空気減少量の関係

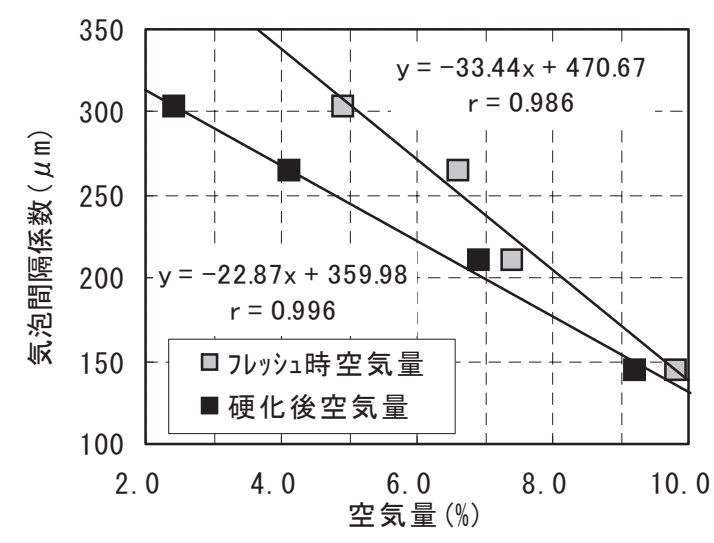

図-2 空気量と気泡間隔係数の関係

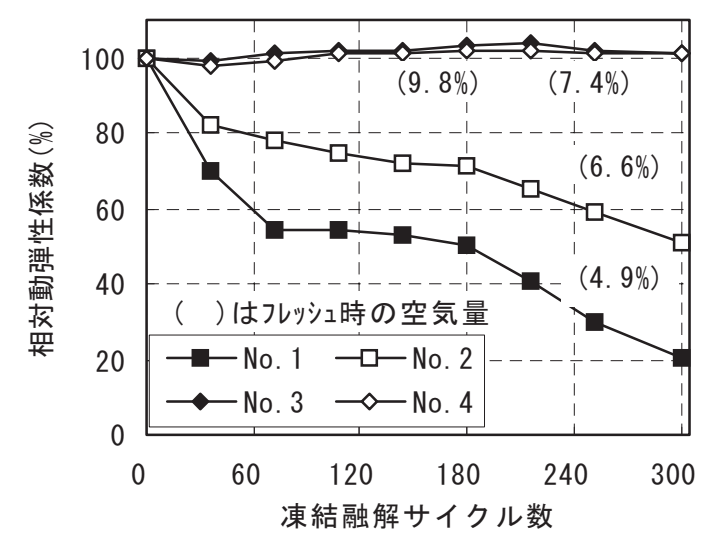

図－3 凍結融解サイクル数と相対動弾性係数の関係 


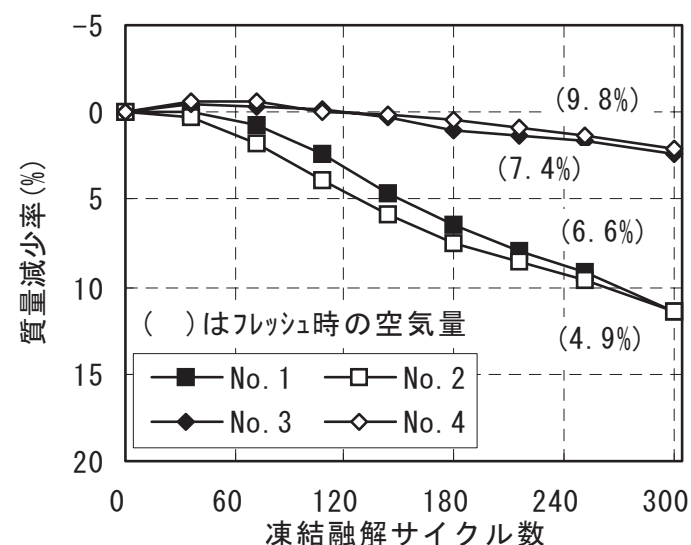

図－4 凍結融解サイクル数と質量減少率の関係
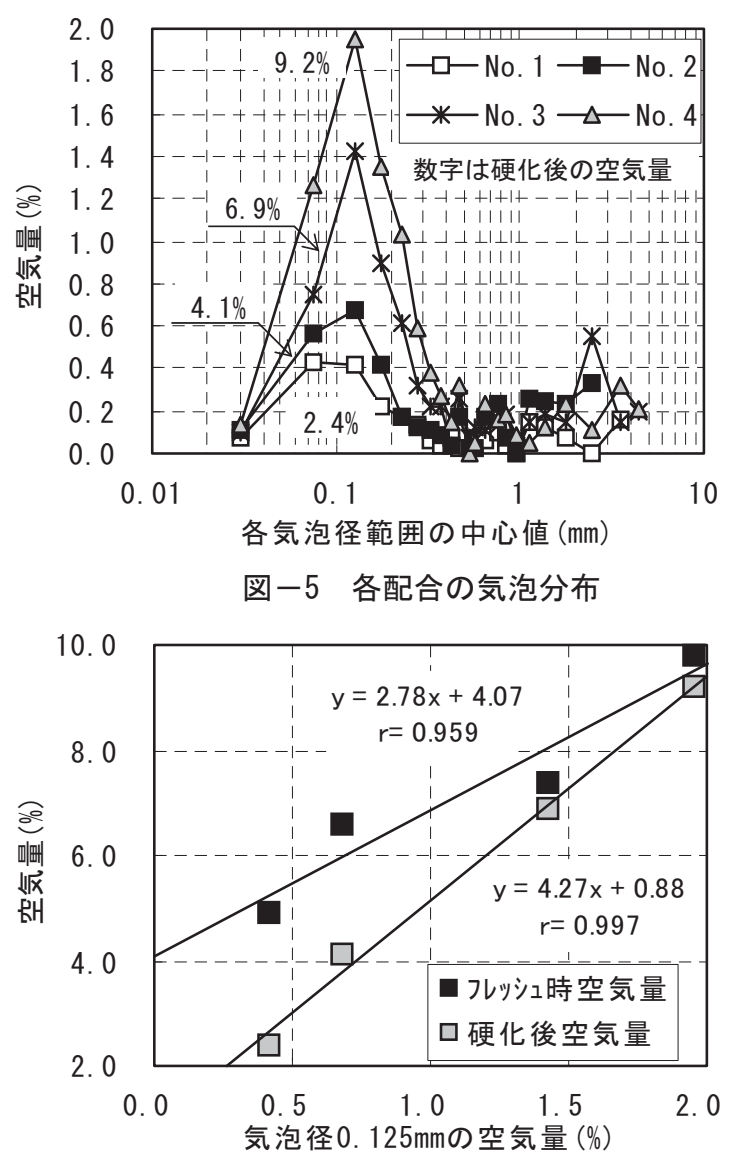

図－6 気泡径 0.125mm の空気量とフレッシュ時 および硬化後空気量の関係

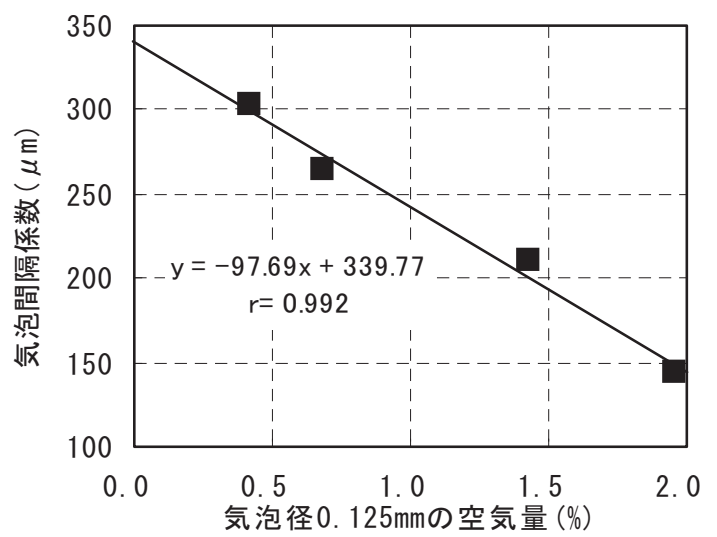

図-7 気泡径 $0.125 \mathrm{~mm}$ の気泡量と気泡間隔係数の関係

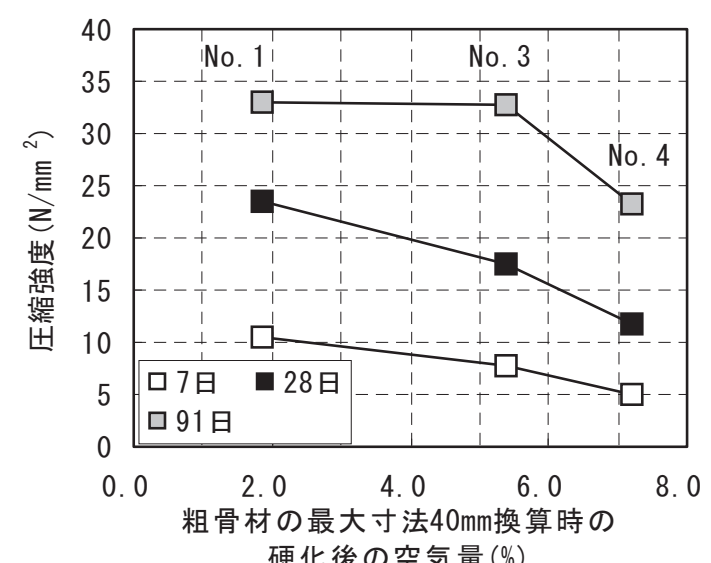

図-8 硬化後の空気量と圧縮強度の関係

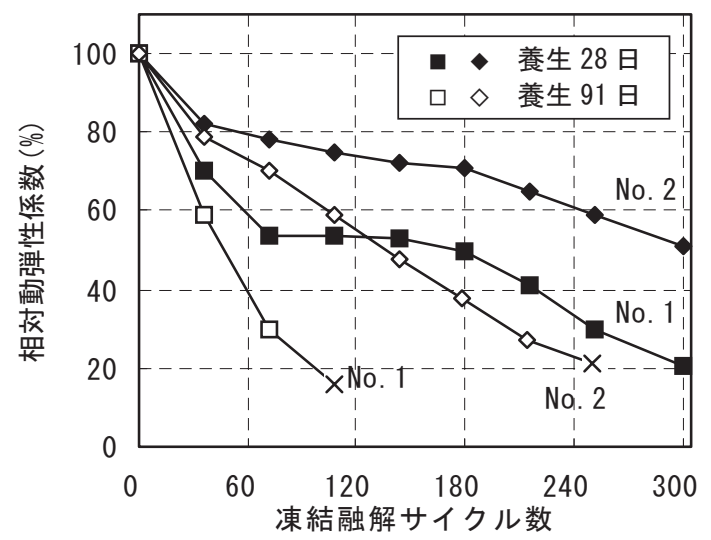

図－9 試験開始材齢の異なる凍結融解試験結果

図-8に硬化後の空気量と圧縮強度の関係を示す。こ こで, 空気量, 圧縮強度ともに, $40 \mathrm{~mm}$ ふるいでウェッ トスクリーニングしたコンクリートについてのものであ る。図に示すように, 材齢 7 日, 28 日では空気量の増加 とともに圧縮強度が小さくなる傾向にあるが，材齢 91 日では, 配合 No.1〜配合 No.3, 空気量 $1.9 \%$ ．4\%（粗 骨材の最大寸法 $20 \mathrm{~mm}$ 換算時のフレッシュ時の空気量 2.4\%〜 6.9\%）まで圧縮強度はほぼ同じであった。ダムコ ンクリートの場合, 粗骨材の最大寸法が $150 \mathrm{~mm}$ であり, この場合, 空気量を増やした配合 No.3でも目標空気量は 4.0\%である。したがって，ダムコンクリートにおいて， 骨材の品質が良好であれば，中庸熱フライアッシュセメ ントを用いる場合でもフルサイズのコンクリートの目標 空気量を $4.0 \%$ 程度にすることによって, 十分な凍結融解 抵抗性が得られ, かつ所定の圧縮強度が得られるものと 考えられる。

図－9 に，配合 No.1 および No.2 について試験開始材 齢が異なる凍結融解試験結果を示す。配合 No.1 および No.2 は, 前述の試験開始材齢 28 日で, 300 サイクルで相 対動弾性係数が $60 \%$ を下回ったものであるが, 試験開始 材齢を 91 日とした場合, さらに相対動弾性係数の低下が 大きくなった。ダムコンクリートでは，保証材齢が 91 日であることから，2007 年制定コンクリート標準示方書 ダムコンクリート編において,「凍結融解抵抗性試験の開 
始材齢は 91 日を標準とする」とされている。これは, ダ ムコンクリートでは強度発現が遅いセメントを使用する ため材齢 28 日から凍結融解試験を行った場合, 相対動弾 性係数が低下寸ると考えられているからである。しかし， 既往の論文 ${ }^{10}$ においても, 凍結融解試験の開始材齢が 14 日よりも28 日の方が, 相対動弾性係数が小さくなること が示されている。このように，今回の 28 日から 91 日の 材齢経過による耐凍害性の低下についても, 細孔構造と の関係から透水性が低下し, 発生内圧力が増加するため と考えられる。凍結融解作用を受ける実際のダムコンク リートの表面部は, 91 日もの長きに亘って連続して水中 に養生されることはなく, 実現象を考えても凍結融解試 験の開始材齢は, 28 日程度とすることが望ましいと考え られる。

\section{3. 凝結過程における空気量の変化}

凝結過程における空気量の変化を検討寸るため, 普通 ポルトランドセメント（以下 OPC）およびMF30 を用い たモルタルについて，ブリーディングに伴う体積変化を 確認する以下の実験を行った。

\section{1 使用材料および配合}

使用材料を表－8 に示す。本実験では，セメントには
OPC と MF30 を用い, 細骨材には砕砂を用いた。実験に 用いた化学混和剤は，リグニンスルホン酸化合物を主成 分とする $\mathrm{AE}$ 減水剤および, 変性ロジン酸化合物系陰イ オン界面活性剤を主成分とする $\mathrm{AE}$ 助剤である。なお, 練混ぜ水には水道水を用いた。

MF30 のモルタルの配合は，水セメント比が $55.0 \%$ の MF30 のコンクリートの配合を基準とし，粗骨材を取り 除いたものとした。OPC のモルタルの配合は MF30 のコ ンクリートの配合と水粉体容積比 $\left(\mathrm{V}_{\mathrm{w}} / \mathrm{V}_{\mathrm{p}}=157.0 \%\right)$ が一 定となるように OPC のコンクリートの配合を定め, 粗骨 材を取り除いたものとした。表一9 にモルタル配合の基 準となるコンクリートの配合を, 表一10にモルタルの配 合をそれぞれ示す。

\section{2 試験方法}

フレッシュモルタルの空気量はJIS A 1128 に従い，モ ルタルエアメータを用い測定した。

モルタルのブリーディングに伴う体積変化を確認する ために次の実験を行った。写真ー1 に示すような $\phi$ $45 \times 500 \mathrm{~mm}$ の円柱のアクリル製の試験容器に高さ $400 \mathrm{~mm}$ の位置までモルタルを詰め，モルタル上面およびブリー ディング水上面の目盛りを, ブリーディングが終了する まで 1 時間間隔で測定した。その際, 試験室内の温度は $20^{\circ} \mathrm{C}$ 一定とした。
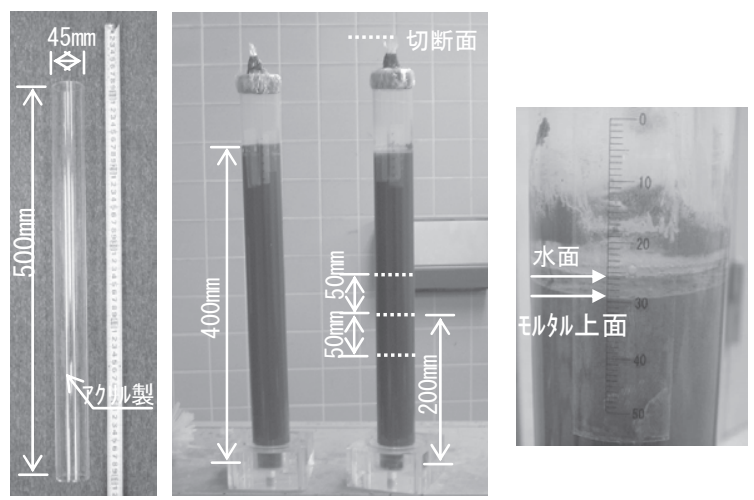

写真-1 試験器具および試験方法

表－9 モルタル配合の基準となるコンクリートの配合

\begin{tabular}{|c|c|c|c|c|c|c|c|c|c|c|c|c|}
\hline \multicolumn{7}{|c|}{ 配合条件 } & \multicolumn{6}{|c|}{ 単位量 $\left(\mathrm{kg} / \mathrm{m}^{3}\right)$} \\
\hline $\begin{array}{l}\text { セメト } \\
\text { 種類 }\end{array}$ & $\begin{array}{c}\text { 粗骨材の } \\
\text { 最大寸法 } \\
\text { (mm) }\end{array}$ & $\begin{array}{l}\mathrm{W} / \mathrm{C} \\
(\%)\end{array}$ & $\begin{array}{c}\mathrm{V}_{\mathrm{w}} / \mathrm{V}_{\mathrm{p}} \\
(\%)\end{array}$ & $\begin{array}{l}\text { S/a } \\
(\%)\end{array}$ & 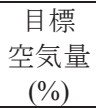 & $\begin{array}{r}\text { 目標 } \\
\text { スランク゚ } \\
(\mathrm{cm})\end{array}$ & $\begin{array}{l}\text { 水 } \\
\mathrm{W}\end{array}$ & $\begin{array}{c}\text { セメン } \\
\mathrm{C}\end{array}$ & $\begin{array}{c}\text { 細骨材 } \\
\text { S }\end{array}$ & $\begin{array}{c}\text { 粗骨材 } \\
20 \sim 05 \\
\text { G }\end{array}$ & $\begin{array}{c}\mathrm{Ad} 1 \\
(\mathrm{C} \times \%)\end{array}$ & $\begin{array}{c}\mathrm{Ad}^{*{ }^{11}} \\
\text { (A) }\end{array}$ \\
\hline OPC & \multirow{2}{*}{20} & 49.6 & \multirow{2}{*}{157.0} & \multirow{2}{*}{44.0} & \multirow{2}{*}{4.5} & \multirow{2}{*}{12.0} & 175 & 353 & 779 & 992 & 0.25 & 3 \\
\hline MF30 & & 55.0 & & & & & 175 & 318 & 779 & 992 & 0.25 & 15 \\
\hline
\end{tabular}

*1)Ad2 はセメント質量に対して $0.001 \%$ 基本量 1A とした。

表一10 モルタルの配合

\begin{tabular}{|c|c|c|c|c|c|c|c|c|c|c|c|c|}
\hline \multicolumn{7}{|c|}{ 配合条件 } & \multicolumn{6}{|c|}{ 単位量 $\left(\mathrm{kg} / \mathrm{m}^{3}\right)$} \\
\hline $\begin{array}{l}\text { セント } \\
\text { 種類 }\end{array}$ & $\begin{array}{c}\text { 粗骨材の } \\
\text { 最大寸法 } \\
(\mathrm{mm})\end{array}$ & $\begin{array}{l}\mathrm{W} / \mathrm{C} \\
(\%)\end{array}$ & $\begin{array}{c}\mathrm{V}_{\mathrm{w}} / \mathrm{V}_{\mathrm{p}} \\
(\%)\end{array}$ & $\begin{array}{l}\text { s/a } \\
(\%)\end{array}$ & $\begin{array}{c}\text { 目標 } \\
\text { 空気量 } \\
(\%)\end{array}$ & $\begin{array}{l}\text { 目標 } \\
\text { スラフプ } \\
(\mathrm{cm})\end{array}$ & $\begin{array}{l}\text { 水 } \\
\mathrm{W}\end{array}$ & $\begin{array}{c}\text { セメン } \\
\mathrm{C}\end{array}$ & $\begin{array}{c}\text { 細骨材 } \\
\text { S }\end{array}$ & $\begin{array}{c}\text { 粗骨材 } \\
20 \sim 05 \\
\text { G }\end{array}$ & $\begin{array}{c}\text { Ad1 } \\
(\mathrm{C} \times \%)\end{array}$ & $\begin{array}{c}\mathrm{Ad}^{* 11} \\
(\mathrm{~A})\end{array}$ \\
\hline OPC & & 49.6 & 1570 & & $7 ?$ & & 280 & 564 & 1245 & - & 0.25 & 3 \\
\hline MF30 & & 55.0 & 101.0 & & 1.2 & & 280 & 508 & 1245 & - & 0.25 & 43 \\
\hline
\end{tabular}

*1)Ad2 はセメント質量に対して $0.001 \%$ 基本量 $1 \mathrm{~A}$ とした。 
モルタル硬化後は水中養生を行い, 材齢 14 日以降に, 写真 -1 に示す中央部および中央部から上下方向に $50 \mathrm{~mm}$ の位置の 3 力所を厚さ $20 \mathrm{~mm}$ 程度で切断し, ASTM C 457 （リニアトラバース法）に準じて, 硬化後の空気量 を測定した。なお, 測定回数は各力所で 1 回とし, 3 つ の平均值を硬化後の空気量とした。

\section{3 試験結果および考察}

図ー10に, 練上り後の経過時間と目盛りの読み值を示 す。図において, 目盛り 0 は打込夕直後のモルタル上面 であり，、印はブリーディング水面を示しており，0 か らム印までの下がりがモルタルの体積減少量である。ま

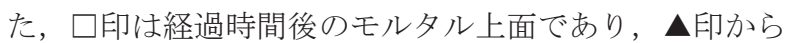
口印までがブリーディング水量になる。図に示すように, ブリーディングが終了する時間は, OPC が 4 時間に対し て MF30 は 5 時間と 1 時間遅くなったが，ブリーディン グ量は，OPC および MF30 ともに，ほぼ同じであった。 それに対して, 体積減少量は, OPC が $1.5 \mathrm{~mm}$ に対して, MF30 は 4.0mm となっていることが分かる。写真一2 お よび写真ー3に，OPC および MF30 を用いたモルタルの 上面の状況をそれぞれ示す。写真に示すように, OPCで はブリーディング水上面に空気泡がわずかに観察される 程度であったのに対して, MF30 では空気泡が数多く観 察された。大きな径の気泡ほど浮き上がる速度が速い現 象を踏まえると, MF30 の方が大きな径の気泡が多くな っているものと考えられる。フレッシュ時に導入された 気泡がもともと大きい，あるいは，凝結過程において微 細な独立した気泡径同士が破泡や合泡することで結合し， より大きな径の気泡が形成されたために，上面の気泡の 浮きが OPC よりも多くなったことが要因として考えら れた。また, 表一11に示すように, フレッシュモルタル の空気量と硬化モルタルの 3 力所の平均の空気量を比較 すると, OPC が 0.2\%低下したのに対して, MF30 は 2.2\% 低下した。このことから, MF30を用いたモルタルでは, 打込み後, 凝結過程でモルタル中の空気が空気泡として 抜けたものと考えられる。千歩らは，フライアッシュを 使用した場合, $\mathrm{AE}$ 剂によって連行された気泡は, 静置 によってその組織が変化しやすく, 気泡の安定性が低く なるとしている ${ }^{5)}$ 。本研究においても同様に，フライア ッシュを使用した場合, OPCに比べて気泡の安定性が低 くなる結果となった。その理由として, 凝結過程におい て発生するブリーディングの流れが気泡の安定性を低下 させ, 破泡や合泡を生じさせている可能性が推察された。

\section{4. ブリーディング量の違いが気泡組織に及ぼ す影響}

ブリーディング量を意図的に変えた場合の気泡組織の 変化を把握するため, OPC および MF30 を用いたコンク リートについて，コンクリート温度を変化させた以下の

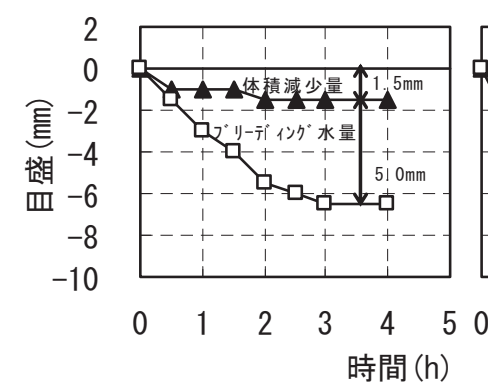

(a) $\mathrm{OPC}$



(b) MF30

\section{図ー10 モルタルの経時による体積変化}

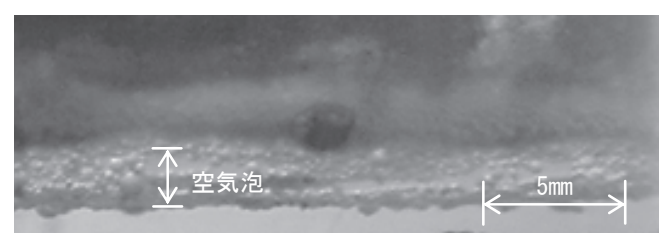

写真－2 モルタル上面の状況 (OPC)

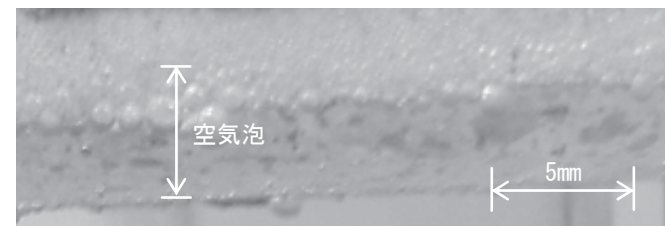

写真－3 モルタル上面の状況 (MF30)

表-11 フレッシュ時および硬化後空気量の比較

\begin{tabular}{|c|c|c|c|}
\hline $\begin{array}{c}\text { セxト } \\
\text { 種類 }\end{array}$ & $\begin{array}{c}\text { 1)フッシュ時 } \\
\text { 空気量(\%) }\end{array}$ & $\begin{array}{c}\text { (2)硬化後 } \\
\text { 平均 } \\
\text { 空気量 }(\%)\end{array}$ & $\begin{array}{c}\text { (1)-(2) } \\
(\%)\end{array}$ \\
\hline OPC & 7.0 & 6.8 & 0.2 \\
\hline MF30 & 7.2 & 5.0 & 2.2 \\
\hline
\end{tabular}

表 -12 使用材料

\begin{tabular}{|c|c|c|}
\hline 種 類 & 記 号 & 摘 要 \\
\hline $\begin{array}{c}\text { 普通 } \\
\text { ポルトランドセメン }\end{array}$ & $\mathrm{OPC}$ & $\begin{array}{l}\text { 密度: } 3.16 \mathrm{~g} / \mathrm{cm}^{3} \\
\text { 比表面積 : } 3,310 \mathrm{~cm}^{2} / \mathrm{g}\end{array}$ \\
\hline $\begin{array}{c}\text { フライ⿰亻ッシュ 30\%混入 } \\
\text { 中庸熱ポルトランドセメト }\end{array}$ & MF30 & $\begin{array}{l}\text { 密度: } 2.85 \mathrm{~g} / \mathrm{cm}^{3} \\
\text { 比表面積 : } 3,750 \mathrm{~cm}^{2} / \mathrm{g}\end{array}$ \\
\hline 細骨材 & $\mathrm{S}$ & $\begin{array}{l}\text { 密度 : } 2.65 \mathrm{~g} / \mathrm{cm}^{3} \text { (表乾) } \\
\text { 吸水率 }: 1.01 \%\end{array}$ \\
\hline $\begin{array}{c}\text { 粗骨材 } \\
(20 \sim 5 \mathrm{~mm})\end{array}$ & G & $\begin{array}{l}\text { 密度 : } 2.65 \mathrm{~g} / \mathrm{cm}^{3} \text { (表乾) } \\
\text { 吸水率 }: 0.60 \%\end{array}$ \\
\hline $\mathrm{AE}$ 減水剂 & Ad1 & $\begin{array}{l}\text { リグニンスルホ、酸化合物と } \\
\text { ポリオールの複合体 }\end{array}$ \\
\hline $\mathrm{AE}$ 助剤 & $\mathrm{Ad} 2$ & $\begin{array}{l}\text { 変性口ジン酸化合物系 } \\
\text { 陰仏界面活性剂 }\end{array}$ \\
\hline 練混ぜ水 & $\mathrm{W}$ & 水道水 \\
\hline
\end{tabular}

実験を行った。

\section{1 使用材料}

使用材料を表一12 に示す。セメントには OPC と MF30 を用い, 細骨材および粗骨材には砕砂, 砕石を使用した。 なお, 粗骨材の最大寸法は $20 \mathrm{~mm}$ とした。実験に使用し た化学混和剤は, $\mathrm{AE}$ 減水剂および $\mathrm{AE}$ 助剤を用いた。 $\mathrm{AE}$ 減水剂はリグニンスルホン酸化合物を主成分とする ものを使用し, $\mathrm{AE}$ 助剤については, 変性ロジン酸化合 
表ー13 コンクリートの配合

\begin{tabular}{|c|c|c|c|c|c|c|c|c|c|c|c|c|c|}
\hline \multicolumn{8}{|c|}{ 配合条件 } & \multicolumn{6}{|c|}{ 単位量 $\left(\mathrm{kg} / \mathrm{m}^{3}\right)$} \\
\hline 配合名 & $\begin{array}{c}\text { コンクリート } \\
\text { 温度 } \\
\left({ }^{\circ} \mathrm{C}\right)\end{array}$ & $\begin{array}{c}\text { 粗骨材 } \\
\text { の最大 } \\
\text { 寸法 } \\
(\mathrm{mm})\end{array}$ & $\begin{array}{l}\mathrm{W} / \mathrm{C} \\
(\%)\end{array}$ & $\begin{array}{c}\mathrm{V}_{\mathrm{w}} / \mathrm{V}_{\mathrm{p}} \\
(\%)\end{array}$ & $\begin{array}{c}\text { s/a } \\
(\%)\end{array}$ & $\begin{array}{l}\text { 目標 } \\
\text { スラフプ } \\
(\mathrm{cm}) \\
\left.{ }^{* 1}\right)\end{array}$ & $\begin{array}{c}\text { 目標 } \\
\text { 空気 } \\
\text { 量 } \\
(\%)\end{array}$ & $\begin{array}{l}\text { 水 } \\
\mathrm{W}\end{array}$ & $\begin{array}{c}\text { セメント } \\
\mathrm{C}\end{array}$ & $\begin{array}{c}\text { 細骨 } \\
\text { 材 } \\
\text { S }\end{array}$ & $\begin{array}{c}\text { 粗骨 } \\
\text { 材 } \\
20 \sim 05 \\
\text { G }\end{array}$ & $\begin{array}{l}\mathrm{Ad} 1 \\
(\mathrm{C} \times \%)\end{array}$ & $\begin{array}{l}\mathrm{Ad} 2 \\
*_{2} \\
\text { (A) }\end{array}$ \\
\hline OPC-5 & \multirow{2}{*}{5} & \multirow{6}{*}{20} & 49.6 & \multirow{6}{*}{157.0} & \multirow{6}{*}{44.0} & \multirow{6}{*}{12.0} & \multirow{6}{*}{4.5} & 175 & 353 & 779 & 992 & 0.25 & 3 \\
\hline MF30-5 & & & 55.0 & & & & & 175 & 318 & 779 & 992 & 0.25 & 16 \\
\hline OPC-20 & \multirow{2}{*}{20} & & 49.6 & & & & & 175 & 353 & 779 & 992 & 0.25 & 3 \\
\hline MF30-20 & & & 55.0 & & & & & 175 & 318 & 779 & 992 & 0.25 & 19 \\
\hline OPC-30 & \multirow{2}{*}{30} & & 49.6 & & & & & 175 & 353 & 779 & 992 & 0.25 & 5 \\
\hline MF30-30 & & & 55.0 & & & & & 175 & 318 & 779 & 992 & 0.25 & 26 \\
\hline
\end{tabular}

*1)コンクリート温度 $20^{\circ} \mathrm{C} の$ 目標スランプ

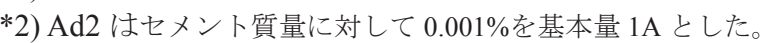

物系陰イオン界面活性剤を主成分とするものを用いた。 また，練混ぜ水には，水道水を使用した。

コンクリートの配合を表ー13 に示す。単位水量は $175 \mathrm{~kg} / \mathrm{m}^{3}$ で一定とし, MF30 の配合については水セメン 卜比 $55.0 \%, \mathrm{OPC}$ の配合は MF30 の配合と同一の水粉体 容積比（ $\mathrm{V}_{\mathrm{w}} / \mathrm{V}_{\mathrm{p}}=157.0 \% ）$ となるように定めた。コンクリ ートの練上り温度および養生温度は， $5^{\circ} \mathrm{C}, 20^{\circ} \mathrm{Cおよび}$ $30^{\circ} \mathrm{C}$ の 3 水準とし, 目標空気量 $4.5 \pm 0.5 \%$ となるように $\mathrm{AE}$ 助剤で調整を行った。

\section{2 試験方法}

フレッシュコンクリートのスランプおよび空気量は, それぞれ，JIS A 1101 およびJIS A 1128 に従い測定した。 さらに, フレッシュコンクリートの性質に関する試験と して，ブリーディング試験および凝結試験を行った。ブ リーディング試験は JIS A 1123 に準じて実施し，ブリー ディング率を算出した。凝結試験は, 練上がり直後のコ ンクリートを $5 \mathrm{~mm}$ ふるいでウェットスクリーニングし たモルタルの試料を用いた。そして，JIS A 1147 に従い 貫入抵抗試験装置を使用し, 貫入抵抗值が $3.5 \mathrm{~N} / \mathrm{mm}^{2}$ に なるまでの時間をコンクリートの始発時間, 貫入抵抗值 が $28.0 \mathrm{~N} / \mathrm{mm}^{2}$ になるまでの時間をコンクリートの終結時 間とした。

硬化コンクリートについては，気泡間隔係数測定を行 った。気泡間隔係数測定は， $\phi 150 \times 300 \mathrm{~mm}$ の円柱供試 体の中心部を厚さ $20 \mathrm{~mm}$ で切断し, ASTM C 457 (リニ アトラバース法）により硬化コンクリートの空気量およ び気泡間隔係数を測定した。なお, 供試体の本数は 1 本, 測定回数は 1 回とした。

\section{3 試験結果および考察}

図ー11 にブリーディング試験結果を, 図ー12 に凝結試 験結果を示す。図ー11 に示すように，ブリーディング率 は各温度で OPC よりも MF30 の方が大きくなった。しか し, その程度は, コンクリート温度 $20^{\circ} \mathrm{C}, 30^{\circ} \mathrm{C}$ では, $\mathrm{OPC}$ および MF30 のブリーディング率はほとんど変わらなか ったのに対し，コンクリート温度 $5^{\circ} \mathrm{C}$ では MF30の方が $\mathrm{OPC}$ に比べ 2 倍程度であった。図ー12 に示すように，コ

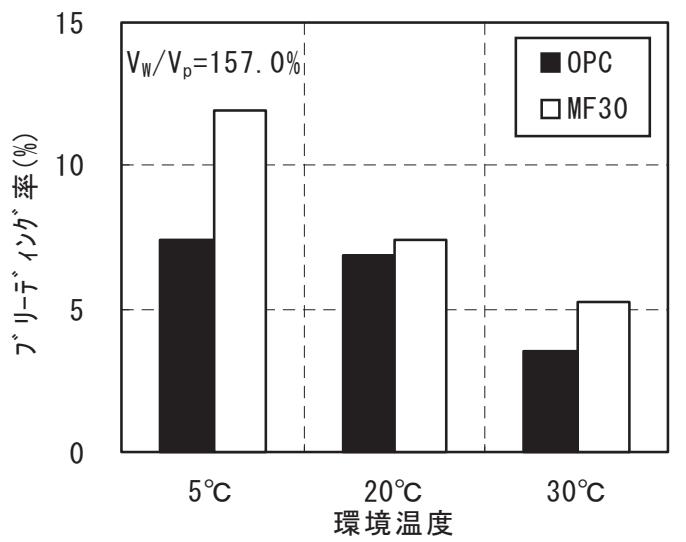

図ー11 ブリーディング試験結果

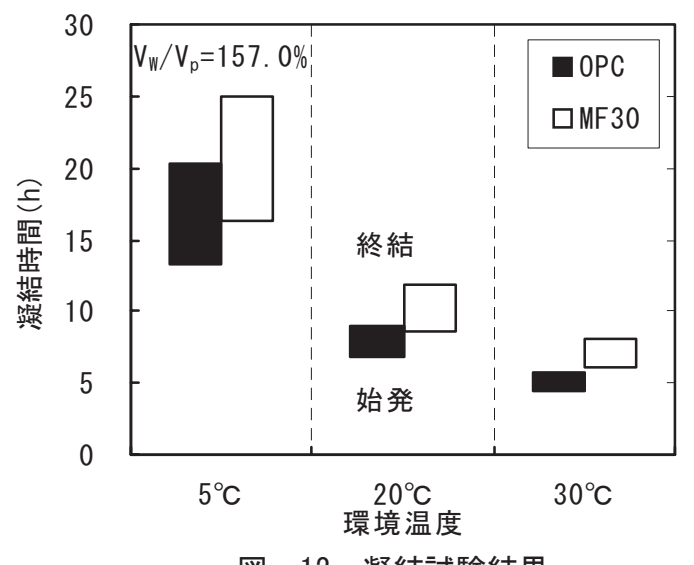

図 -12 凝結試験結果

表-14 空気量および気泡間隔係数

\begin{tabular}{|c|c|c|c|c|}
\hline 配合名 & $\begin{array}{c}\text { (1)レッシュ } \\
\text { 空気量 } \\
(\%)\end{array}$ & $\begin{array}{c}\text { (2)硬化 } \\
\text { 後空気 } \\
\text { 量(\%) }\end{array}$ & $\begin{array}{c}\text { (1)-(2)空 } \\
\text { 気減少 } \\
\text { 量 }(\%)\end{array}$ & $\begin{array}{c}\text { 気泡間 } \\
\text { 隔係数 } \\
(\mu \mathrm{m})\end{array}$ \\
\hline OPC-5 & 4.3 & 3.6 & 0.7 & 361 \\
\hline MF30-5 & 4.3 & 2.1 & 2.2 & 423 \\
\hline OPC-20 & 4.4 & 3.8 & 0.6 & 314 \\
\hline MF30-20 & 4.3 & 3.0 & 1.3 & 322 \\
\hline OPC-30 & 4.6 & 4.5 & 0.1 & 300 \\
\hline MF30-30 & 4.6 & 3.4 & 1.2 & 350 \\
\hline
\end{tabular}





図ー15 ブリーディング率と硬化後の空気量の関係

ンクリート温度が低い方が凝結時間は長くなり，MF30 の方が OPCよりも長くなった。特に, MF30では, コン クリート温度 $5^{\circ} \mathrm{C}$ 条件で凝結時間が大幅に長くなった。

表一14 に各ケースのフレッシュ時の空気量, 硬化後の 空気量および気泡間隔係数を示す。図ー13にフレッシュ 時の空気量と硬化後の空気減少量の関係を示す。OPC で は硬化後の空気減少量が $0.1 \sim 0.7 \%$ であたのに対して, MF30 では 1.2～2.2\%と大きくなっていることが分かる。 また，セメントごとに見ると，コンクリート温度が低い ほど硬化後の空気減少量が大きくなっており，この傾向 は MF30 を用いたコンクリートでより顕著であった。 図-14 にブリーディング率と硬化後の空気減少量の

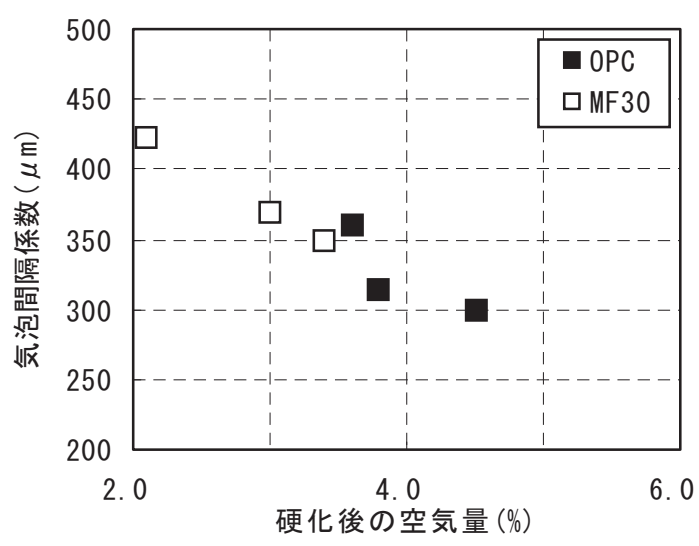

図-16 硬化後の空気量と気泡間隔係数の関係

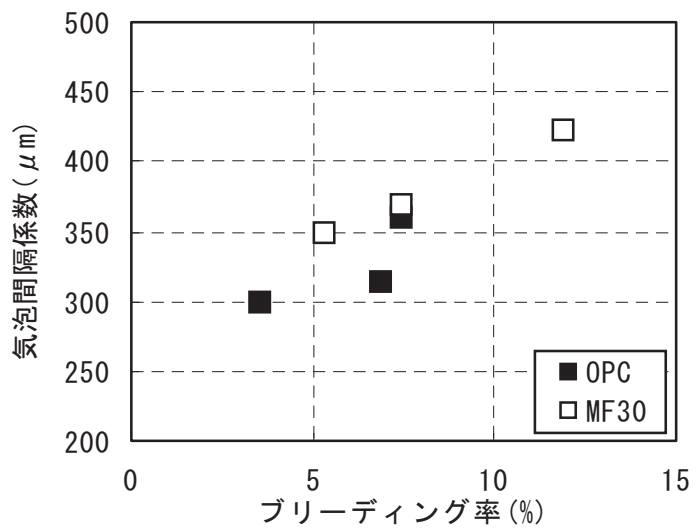

図-17 ブリーディング率と気泡間隔係数の関係

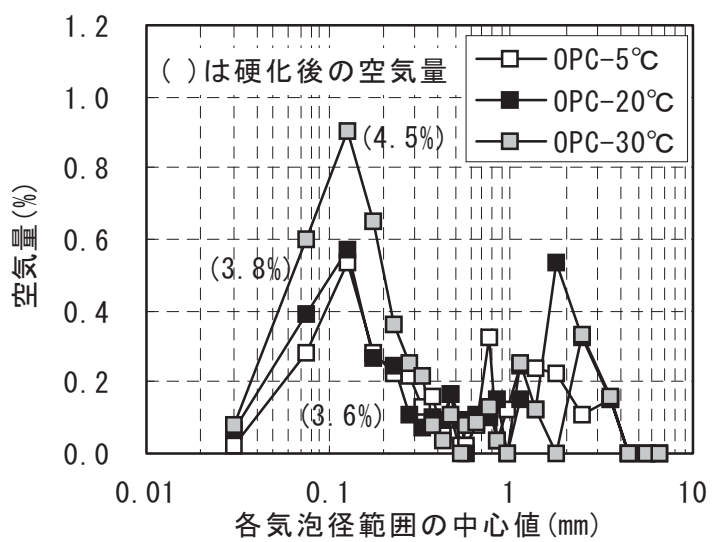

(a) $\mathrm{OPC}$

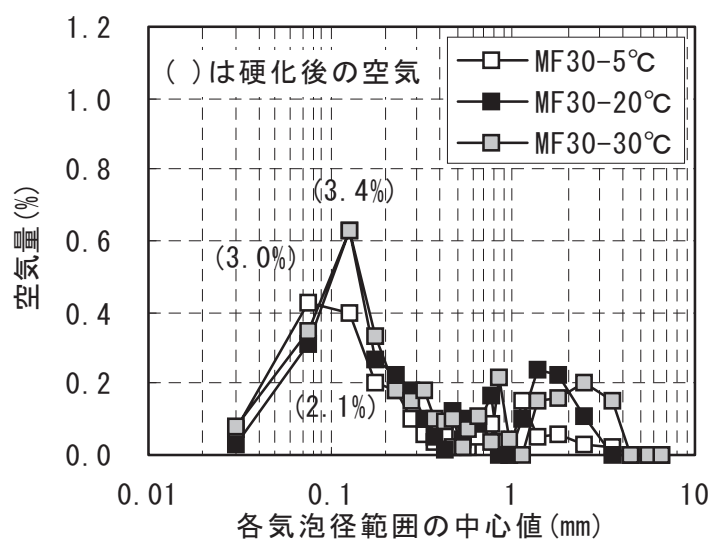

(b) MF30

図-18 気泡分布 
関係を, 図ー15にブリーディング率と硬化後の空気量の 関係をそれぞれ示す。今回の実験では，フレッシュ時の 目標空気量を $4.5 \pm 0.5 \%$ として，実際には各ケースで 4.3 〜 4.6\%となったことから, 図ー14 と図ー15 はほぼ同じ 関係となっている。図に示すように，ブリーディング率 が大きいほど, 硬化後の空気減少量が大きくなり, 硬化 後の空気量が小さくなることが分かる。また，同じブリ ーディング率の場合, MF30の方が OPCよりも硬化後の 空気減少量が大きくなった。このことは，3 章でのモル タルによる検討と一致するものであり, フライアッシュ を用いたコンクリートの場合, ブリーディングの流れに よってコンクリート中の気泡の安定性が低下し, 破泡や 合泡したためであると考えられる。

図一16に硬化後の空気量と気泡間隔係数の関係を, 図 -17 にブリーディング率と気泡閒隔係数の関係をそれ ぞれ示す。罒に示すように, 硬化後の空気量と気泡間隔 係数には高い相関があるとともに，ブリーディング率と 気泡間隔係数にも高い相関があることが分かる。図ー18 に各セメントの気泡分布を示す。眓に示すように，各尔 一スともに $0.125 \mathrm{~mm}$ の気泡に差が認められ, 硬化後の空 気量が大きいほど，また OPC の方が $0.125 \mathrm{~mm}$ の気泡が 多くなっていることが分かる。

以上から，ブリーディングが多いほどフレッシュ時か ら硬化後の空気減少量が大きくなり, その程度は, OPC を用いたコンクリートよりも MF30 を用いたコンクリー トの方が顕著であることが分かった。

\section{5. まとめ}

本研究では，フライアッシュを用いたコンクリートの 中でも，ダムコンクリートで一般に用いられている中庸 熱フライアッシュセメントに着目し，コンクリートの凝 結過程における空気量の変化を把握し, 気泡組織と耐凍 害性との関係を明らかにすることを目的として，実験的 に検討した。その結果，以下のことが明らかとなった。

1) 中庸熱フライアッシュセメントを用いた場合，一般 に設定されている空気量（ダムコンクリートの粗骨 材フルサイズコンクリートの目標空気量 $3.0 〜 3.5 \%$ ) では, フレッシュコンクリートの空気量が硬化後に 大幅に減少する。また，この空気量の減少によって， 凍結融解抵抗性が著しく低下寸る。

2) 中庸熱フライアッシュセメントを用いた場合で，粗 骨材フルサイズコンクリートの目標空気量を $4.0 \%$ 以上に設定することで，硬化後の空気減少量を抑制 でき，硬化後の空気量を確保できることから，所定 の凍結融解抵抗性を有するコンクリートが得られ る。また，粗骨材フルサイズコンクリートの目標空 気量 $4.0 \%$ で，91 日圧縮強度の低下も小さい。よっ て，ダムコンクリートにおいて中庸熱フライアッシ
ユセメントを用いる場合には，目標空気量の設定値 をある程度大きくする必要がある。

3) 同じブリーディング率のコンクリートであっても, 中庸熱フライアッシュセメントを用いた方が，普通 ポルトランドセメントを用いるよりも，硬化後の空 気減少量が大きくなる。この理由として，フライア ッシュ混入により，コンクリート中の気泡の安定性 が低下し，さらにブリーディングの流れによって破 泡や合泡の現象が生じるためであると考えられる。

4) 同一セメントを用いる場合, ブリーディングが多い ほどフレッシュ時から硬化後の空気減少量が大き くなる。また, その傾向は MF30の方が顕著である。

謝辞 : 本研究にあたり，BASF ポゾリス株式会社，混和 剂開発グループの作榮二郎氏からコンクリート試験に関 するご協力ならびにご助言を頂きました。ここに深く感 謝の意を表します。

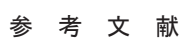

1）国土交通省 国土技術政策総合研究所: 国土技術政策総合研究所資 料 ダム補修事例に関する調查，第 262 号，pp.4-38，2005.6

2）木下昌樹, 鎌形辰男, 濱野久美 : 矢木沢ダム堤体コンクリート調査 結果報告，ダム技術，No.215，pp.42-56，2004.8

3）小田島公一, 及川薫, 伊藤博, 竹内幸紘 : 遠野ダムの堤体老朽化対 策について, 大ダム, No.191, pp.27-35, 2005.4

4）長澈重義, 大賀宏行, 嶋田久俊 : フライアッシュを混和したコンク リートの耐凍害性評価, セメント技術年報, No.41, pp.371-374, 1987

5）千歩修, 劉宏涛 : フライアッシュコンクリートの静置による気泡組 織·而凍害性の変化, 日本建築学会大会学術講演梗概集, pp.963-964, 2004.8

6）庄谷征美，杉田修一，月永洋一：フェロニッケルスラグ細骨材を用 いたコンクリートの凍結融解抵抗性に関する研究，材料，Vol.43， No.491, pp.976-982, 1994.8

7）阿波稔, 庄谷征美, 杉田修一, 後藤努 : コンクリートの組織構造に 及ぼすブリーディングの影響に関する研究, セメント・コンクリー 卜論文集，No.54，pp.195-201，2000

8）山本隆信, 杉山隆文, 辻幸和：フライアッシュコンクリートの空気 連行性およびブリーディングに影響を及ぼす各種要因, コンクリー 卜工学年次論文報告集，Vol.20，No.2，pp.97-102，1998

9）奥野亨, 浅野研一, 大浦鉄男 : フライアッシュコンクリートの空気 連行性について，セメント技術年報， No.38，pp.150-153，1984

10）堺孝司，熊谷守晃，吉田行，若杉伸一：ビーライト系セメントを用 いたコンクリートの凍結融解抵抗性, 土木学会論文集, No.718/V-57, pp.33-44, 2002.11

（原稿受理年月日：2011 年 3 月 16 日） 
Influence of Air Content on Frost Damage Resistance of

Moderate-Heat Portland Cement Concrete with Fly Ash in Setting Process

By Noboru Sakata, Takumi Sugamata, Daisuke Hayashi and Manabu Hashimoto

Concrete Research and Technology, Vol.22, No.3, Sep. 2011

Synopsis: This study focused on air-entraining capability and resulting freeze and thaw resistance in moderate-heat Portland cement concrete with fly ash (MHC-FA concrete) which is generally applied for dam construction. Experimental results demonstrated that entrained air tends significantly to decrease during fresh states with time in MHC-FA concrete, which leads to deteriorating freeze and thaw resistance. This phenomenon appears to be caused by bleeding, which destroys air bubbles in MHC-FA concrete more than in normal concrete. Therefore, MHC-FA concrete with higher bleeding amounts shows more remarkably decreasing air contents. As a result, the authors propose to initially introduce higher entraining air amount to maintain freeze and thaw resistance in MHC-FA concrete.

Keywords: fly ash, bleeding, air void system, air void spacing factor, freezing and thawing resistance 